\title{
DIE AFWENDING (DIVERSION) VAN VOLWASSENES EN VEREISTES WAARAAN SOGENAAMDE WENSLIKHEID VAN VERVOLGING- VERSLAE MOET VOLDOEN
}

\section{Elizabeth Vergottini, Mike Weyers}

\section{INLEIDING}

Die misdaadprobleem en oorvol korrektiewe sentra waarmee Suid-Afrika worstel, vereis kreatiewe oplossings. Een hiervan is die afwending (diversion) van volwassenes. Dié opsie behels basies die kanalisering van prima facie-sake, met of sonder voorwaardes, weg van die strafregtelike sisteem af (Badenhorst \& Conradie, 2004:115). Dit bied nie net aan beskuldigdes die geleentheid om sonder 'n skuldigbevinding in die gemeenskap te rehabiliteer nie, maarverlig terselfdertyd die druk op korrektiewe sentra.

Afwending word reeds sedert die vroeë 1990's in Suid-Afrika benut en daar is sedertdien 'n beduidende groei in die getal jeugdige oortreders wat die proses deurloop (Wood, 2003:1). Die betrokke opsie hoef egter nie net tot jeugdiges beperk te word nie. Die Suid-Afrikaanse strafreg maak daarvoor voorsiening dat die Direkteur van Openbare Vervolging via plaaslike aanklaers klagtes, met of sonder voorwaardes, teen enige persoon kan terugtrek (Wet 51/1977: Art. 6). Dit sluit dus, per implikasie, ook volwassenes in.

Alhoewel proefbeamptes in diens van die Departement van Maatskaplike Ontwikkeling reeds in sommige sentra genader word om sake rakende volwasse oortreders te ondersoek en aanbevelings in hierdie verband aan die hof te doen, is dit nog nie algemene praktyk nie. Daar bestaan ook geen duidelikheid oor die vereistes wat in hierdie verband nagekom moet word en die verwagtinge waaraan die gepaardgaande "wenslikheid van vervolging"-verslae moet voldoen nie. Hierdie tweeledige probleem het daartoe aanleiding gegee dat beide die statutêre begronding van die afwending van volwassenes en die aanvraers se verwagtinge rakende die benodigde ondersoek en verslag deur middel van navorsing verken moes word.

\section{BEGRONDING VAN DIE AFWENDING VAN VOLWASSENES}

Die statutêre begronding van die afwending van volwassenes is veral in Artikel 6 van die Strafproseswet (Wet 51/1977) te vinde. Dié artikel lui soos volg:

\section{Bevoegdheid om aanklag terug te trek of vervolging te staak}

Artikel 6: 'n Prokureur-generaal of iemand wat 'n vervolging van staatsweë waarneem of 'n liggaam of persoon wat 'n vervolging ingevolge Artikel 8 waarneem, kan

(a) voordat 'n beskuldigde op 'n aanklag pleit, daardie aanklag terugtrek, in welke geval die beskuldigde nie op vryspraak ten opsigte van daardie klagte geregtig is nie;

(b) te enige tyd nadat die beskuldigde gepleit het, maar voor skuldigbevinding, die vervolging ten opsigte van daardie aanklag staak, in welke geval die hof wat die beskuldigde verhoor die beskuldigde ten opsigte van daardie geval moet vryspreek: Met dien verstande dat waar vervolging deur iemand anders as 'n prokureur-generaal of in artikel 8 bedoelde liggaam of persoon waargeneem word, die vervolging nie gestaak word tensy die prokureur-generaal of iemand deur die prokureur-generaal daartoe gemagtig, hetsy in die algemeen of in 'n bepaalde geval, daartoe ingestem het nie" (Strafproseswet, Wet 51/1977: Art. 6). 
Artikel 6 hou veral twee implikasies vir howe en proefbeamptes in. Eerstens plaas dit geen beperking op die ouderdom van die oortreder of die aard van die oortreding nie. Tweedens dui dit aan dat afwending op 'n voorverhoor- of 'n voorskuldigbevindingsvlak plaasvind. Dit verskil dus van remediërende dienste in terme van byvoorbeeld art. 297 van die Strafproseswet (Wet 51/1977) waar die betrokkene eers skuldig bevind moet word (art. 297 (1)) en dié skuldigbevinding as 'n vorige veroordeling aangeteken word (art. 297 (2)).

Daar bestaan tans in die Strafproseswet (Wet 51/1977) geen spesifieke verwysing na 'n verslag wat 'n proefbeampte rakende die wenslikheid van vervolging aan 'n hof mag of moet lewer nie. Sodanige bepalings rakende proefbeamptes is wel in wetgewing vervat.

In hierdie verband bevat die Wet op Proefdienste (Wet 116/1991) en Wysigingswet op Proefdienste (Wet 35/2002) verskeie bepalings rakende die bevoegdhede en pligte van proefbeamptes in soverre dit afwending aangaan. Artikels 4(1)(i) en (j) van Wet 35/2002 meld spesifiek die volgende:

“Artikel 4(1)(i) Die ontvangs, assessering en verwysing van 'n beskuldigde en die lewering van vroeë ingrypingsdienste en -programme, met inbegrip van bemiddeling en familiegroepkonferering.

“Artikel 4(1)(j) Die ondersoek na die omstandighede van 'n beskuldigde en die verskaffing van 'n voorverhoorverslag wat aanbevelings doen rakende die wenslikheid van vervolging, al dan nie" (kursief deur outeur).

Die betrokke twee artikels impliseer onder andere dat daar van proefbeamptes verwag word om beskuldigdes se omstandighede te ondersoek, te assesseer en aan die hand daarvan verslag aan die hof te doen. Omdat die betrokke soort verslag waarskynlik nie direk aan 'n spesifieke artikel van die Strafproseswet gekoppel is nie en vanweë die wesentlike aard daarvan, het dit in regskringe die benaming wenslikheid van vervolging-verslag (desirability of prosecution report) gekry.

Ten spyte van die statutêre begronding van beide die opsie en die verslag, bestaan daar bykans geen Suid-Afrikaanse literatuur wat die afwending van volwassenes in diepte verken nie. So het 'n literatuursoektog net twee onlangse bronne opgelewer wat daarna verwys dat die afwendingsvereistes wat vir jeugdiges geld, ook vir volwassenes benut kan word, te wete die Nasionale Vervolgingsgesag van Suid-Afrika se Beleidsriglyne (NVG, 1999:12) en die publikasie getiteld Handy Hints for Prosecutors (Collopy, Daffue, Krige, Matzke, Pickett, Sibeko, Phoshoko \& Mulea, 2001:79). Die benutting van die betrokke opsie word verder bemoeilik deur die onsekerheid wat by sommige proefbeamptes en maatskaplike werkers bestaan oor die spesifieke vereistes waaraan die benodigde assesseringsverslae moet voldoen (Steyn, 2001:2-3).

Die bogenoemde dilemma het aanleiding gegee tot 'n navorsingsprojek waarin daar spesifiek gefokus is op die aard van sogenaamde "wenslikheid van vervolging"-verslae vir volwasse oortreders en die verwagtinge wat landdroste en beheeraanklaers daarvan koester. Die navorsingsontwerp en -prosedure wat hierin gevolg is, word vervolgens verken.

\section{NAVORSINGSONTWERP EN -PROSEDURE}

Deurdat die afwending van volwassenes 'n redelik nuwe fenomeen is en daar min literatuur oor die aangeleentheid bestaan, kon daar in die ondersoek slegs van verkennende navorsing gebruik gemaak word. Die doelstellings en doelwitte wat hierin nagestreef en die prosedure wat gevolg is, word vervolgens slegs opsommenderwys weergegee. 


\section{Doelstellings}

In die navorsing is drie basiese doelstellings nagestreef. Dit was naamlik om:

- die statutêre begronding, doel en verwagtinge rakende die afwending vir volwassenes te bepaal;

- sleutelrolspelers in die Departement van Justisie se verwagtinge rakende die inhoud van die benodigde wenslikheid van vervolging-verslae vas te stel; en

- aan die hand van die voorafgaande, riglyne vir die verslae te formuleer.

\section{Afbakening van die ondersoek}

Die verkennende aard van die ondersoek het meegebring dat die tipe respondente wat betrek, die onderwerpe wat aangeraak en geografiese area wat gedek sou word, aan streng afbakening onderwerp moes word. In hierdie verband is net die hoffunksionarisse geteiken wat 'n deurslaggewende rol in die aanvra van wenslikheid van vervolging-verslae speel, te wete landdroste en beheeraanklaers. Slegs twee sentrale onderwerpe is aangeraak, naamlik die betrokkenes se houding jeens die afwending van volwassenes en hul verwagtinge rakende die inhoud van die betrokke tipe verslae.

Die ondersoek is derdens tot die landdroshowe van Kroonstad, Vereeniging en Potchefstroom beperk, omdat al drie geografies in sentraal Suid-Afrika val, maar in drie afsonderlike provinsies (te wete die Vrystaat, Gauteng en Noord-Wes) geleë is. Ook kon hierdeur vir die potensiële verskille in die interpretasie van beleid en prosedures van drie van Suid-Afrika se nege provinsies voorsiening gemaak word.

\section{Die navorsingsprosedure}

Die betrokke navorsingsprosedure het uit die volgende vier basiese stappe bestaan:

- Die eerste stap was 'n omvattende analise van beskikbare literatuur oor die aard en benutting van afwending en van die vereistes waaraan die tersaaklike verslae moet voldoen. Dit het onder andere die nagaan van verskeie Suid-Afrikaanse wette en die beleidsriglyne en ander dokumentasie van die Departement van Justisie en die Departement van Maatskaplike Ontwikkeling ingesluit.

- Die resultate van die literatuurstudie is as basis vir die ontwerp van 'n posvraelys gebruik. Die inhoud van die vraelys is met behulp van 'n onafhanklike beoordelaar en 'n terreindeskundige geverifieer en gedurende Julie 2006 aan al tien die beoogde respondente gepos.

- Die data wat deur die vraelyste gegenereer is, is as basis vir die ontwerp van 'n onderhoudskedule gebruik. Daar is gedurende September 2006 ter plaatse persoonlike onderhoude met al tien die respondente gevoer. Die onderhoude van gemiddeld 30 tot 45 minute elk, is op oudioband opgeneem en volledig getranskribeer.

- Die laaste stap het bestaan uit die indiepte analise van al die data wat deur die ondersoek opgelewer is en die formulering van die benodigde navorsingsverslae.

\section{Die respondente}

Die respondente is op ' $\mathrm{n}$ gestratifiseerde beskikbaarheidsgrondslag geselekteer (Strydom \& Venter, 2002:197-209). Die teikengroep is afgebaken tot een beskikbare landdros en al die beheeraanklaers in die drie gekose howe/dorpe. Die landdroste is gekies omdat hulle leierrolle in howe vertolk en die beheeraanklaers omdat dit deel van hul posbeskrywing is om wenslikheid van vervolging-verslae vanaf proefbeamptes aan te vra. Daar is van die uitgangspunt uitgegaan dat die sienings van twee tipes rolspelers as relatief verteenwoordigend van die 
Departement van Justisie se grondvlak-funksionarisse beskou kan word. Die steekproef het uiteindelik uit drie landdroste en sewe beheeraanklaers bestaan.

\section{Die data-insamelingsinstrumente en verwerking}

Die eerste data-insamelingsinstrument, te wete die posvraelys, het uit 'n totaal van 61 Likerttipe en drie oop vrae bestaan. Dit het ses temas gedek, naamlik:

- die respondente se kennis van en houdings rakende die afwending van jeugdiges en volwassenes;

- die mate waarin hulle reeds van wenslikheid van vervolging-verslae vir beide jeugdiges en volwassenes gebruik maak;

- die tipe oortredings wat by die afwending van volwassenes ingesluit en uitgesluit moet word;

- die kriteria waaraan volwasse oortreders moet voldoen alvorens hulle vir afwending oorweeg kan word;

- die waarde/nuttigheid van bestaande wenslikheid van vervolging-verslae; en

- die inhoudelikes wat in volwassenes se wenslikheid van vervolging-verslae gedek moet word.

Die tweede instrument, te wete die onderhoudskedule, het uit sewe afdelings en 'n totaal van 17 kernvrae bestaan. Deurdat dit in wese ontwikkel is om onduidelikhede in die data wat deur die vraelyste gegenereer is, uit te klaar, het dit dieselfde basiese temas as die vraelys gedek. Daar is egter ook van respondente verwag om aanbevelings rakende die verbetering van die tersaaklike dienste in Suid-Afrika te maak.

Deurdat daar slegs tien respondente was, kon al die data wat deur die vraelyste gegenereer is, per hand verwerk word. Die transkripsies van die onderhoude is deur die navorser en 'n navorsingsassistent geanaliseer. Hierin is daar per afdeling van die onderhoudskedule ' $n$ analise van die respondente se kern- en subresponse gemaak. Hierdie prosedure het dit moontlik gemaak om response te tipeer en te kategoriseer; tendense in 'n respondent se reaksies te identifiseer, en korrelasies tussen die verskillende respondente se reaksies vas te stel.

Dit was laastens moontlik om al die data wat deur die literatuurstudie, die vraelys en onderhoude gegenereer is, te trianguleer en daardeur tot bepaalde gevolgtrekkings te kom. Dit het ook as basis vir die formulering van riglyne vir die opstel en benutting van wenslikheid van vervolgingverslae gedien.

\section{RESULTATE VAN DIE ONDERSOEK}

Die resultate wat deur die ondersoek opgelewer is, kan in vyf kategorieë ingedeel word. Dit raak naamlik die respondente se houdings jeens die afwending van volwassenes, hul siening van die doel van so 'n stap, die kriteria wat in die seleksie van volwasse oortreders gebruik behoort te word, die verwagtinge rakende die inhoud van die verslag en, ten slotte, riglyne vir die formulering van sodanige verslae.

\section{Houdings jeens die afwending van volwassenes}

Die voltooide vraelyste het aangedui dat die oorgrote meerderheid respondente inherent positief teenoor afwending is. Dit is onder andere afgelei uit die feit dat nege van die respondente aangedui het dat hul kantoor tussen een en 20 verslae per maand ten opsigte van jeugdiges aanvra, terwyl sewe ook vermeld het dat hulle tussen een tot 10 verslae per maand vir volwassenes aanvra. Ook het 70\% van die deelnemers gevoel dat afwending 'n werkbare opsie 
vir volwassenes is, terwyl $90 \%$ bevestig het dat hulle meer van afwending vir volwassenes gebruik sou maak indien daar programme in plek was om dit te akkommodeer.

Die bogenoemde voorlopige bevinding is verder met behulp van 'n kernvraag tydens die onderhoude uitgeklaar. Die basiese response wat hierop verkry is, word in tabel 1 weergegee.

TABEL 1

HOUDING JEENS DIE BENUTTING VAN WENSLIKHEID VAN VERVOLGINGVERSLAE EN DIE AFWENDING VAN VOLWASSENES

\section{KERNVRAAG:}

"Hoe voel u oor die algemeen oor die benutting van 'wenslikheid van vervolging'-verslae en die afwending van volwassenes - positief of negatief?"/ "How do you, in general, feel about the use of 'desirability of prosecution' reports and diversion for adults - positive or negative?"

\section{UITTREKSELS UIT DIE BEHEERAANKLAERS SE VERBALE RESPONSE:}

1. "Positive"/“"Baie positief"/“Definitief positief" (vier beheeraanklaers).

2. "Soos jy seker reeds afgelei het, is ek vreeslik positief daaroor."

3. "Ek is positief daaroor. Ek dink inteendeel, as hierdie tipe verslae eintlik vir ons van die begin af beskikbaar gestel kan word op feitlik al ons sake, sal dit vir ons 'n beter persepsie gee oor wat die omstandighede van elke persoon is..."

4. “...ek is 'n voorstander daarvan."

\section{UITTREKSELS UIT DIE LANDDROSTE SE VERBALE RESPONSE:}

1. "Ek is positief daaroor. Ek is heeltemal daarvoor."

2. "Dit is vir my moeilik om te sê omrede dat dit die Aanklaersafdeling is wat dit gebruik, want hulle moet besluit om vervolging in te stel."

3. "Negatief".

Die response soos in tabel 1 vervat, dui daarop dat net een respondent ('n landdros) negatief teenoor die afwending van volwassenes gestaan het, terwyl 'n andere landdros se respons as neutraal beskryf kan word. Die landdros wat negatief teenoor die opsie was, het sy mening daarop geskoei dat volwassenes verantwoordelikheid vir hulle dade moet aanvaar. Dit is opvallend dat al die beheeraanklaers en dus die persone wat uiteindelik die betrokke verslae moet aanvra, dit as 'n goeie opsie beskou het.

\section{Die doel met die afwending van volwassenes}

Afwending kan, aan die hand van tersaaklike Suid-Afrikaanse wetgewing en die sienings van onder andere Nieman (1998:16) en Badenhorst en Conradie (2004:115), omskryf word as die strafregtelike opsie waarin prima facie-sake, in bepaalde omstandighede en met of sonder voorwaardes, weg van die strafregtelike sisteem gekanaliseer word. Die wetgewing maak geen onderskeid tussen die jeugdige en volwasse oortreder nie en dus behoort die doel van die afwending van die betrokke twee groepe wesentlik dieselfde te wees. Of die respondente dit wel so beskou, is in beide die vraelys (tabel 2) en onderhoude (tabel 3) uitgeklaar. 
TABEL 2

DOEL VAN AFWENDING VIR VOLWASSENES: VRAELYS

\begin{tabular}{|l|l|c|c|c|c|c|}
\hline $\begin{array}{l}\text { Statement: The purpose of diversion for } \\
\text { youth and adults are basically the same }\end{array}$ & $\begin{array}{c}\text { Strongly } \\
\text { agree }\end{array}$ & Agree & Neutral & Disagree & $\begin{array}{l}\text { Strongly } \\
\text { disagree }\end{array}$ \\
\hline $\begin{array}{l}\text { Samestelling van } \\
\text { respondente }\end{array}$ & Beheeraanklaers & 2 & 2 & 0 & 3 & 0 \\
\cline { 2 - 7 } & Landdroste & 0 & 1 & 1 & 1 & 0 \\
\hline
\end{tabular}

TABEL 3

DOEL VAN AFWENDING VIR VOLWASSENES: ONDERHOUDSKEDULE

\section{KERNVRAAG:}

"Sou u van mening wees dat afwending van volwassenes dieselfde doel kan dien as vir jeugdiges of is daar'n verskil?/ Do you think that diversion for adults could fulfil the same purpose as that for youths or is there a difference?"

Uittreksels uit die beheeraanklaers se verbale response:

1. "...Nee, dit is maar basies dieselfde doel. Soos ek nou ook in die vorige vrae gesê het, deesdae het ons baie verskillende afwendingsprogramme wat vir elke spesifieke geval geld. Afhangende van die feite van die saak, kan ons 'n baie spesifieke programmetjie aanwend. So, op die ou einde dink ek dit het nog steeds dieselfde doel. Die doel van om so 'n persoon, hetsy hy 'n jeugdige is of 'n volwassene, uit die strafsisteem uit af te wentel."

2. "Wel, dit sal verseker dieselfde tipe doel kan dien. Die groot behoefte op hierdie stadium staan op die basis dat daar alternatiewe gesoek word vir mense tronk toe stuur ten einde die stelsels en die werksaamhede van al die organisasies wat betrokke is by regspleging te verbeter."

3. 'Ja ek glo so, want hoe ons dit meet is aan die sukses 'rate', as ek Engels tussenin praat, of die sake weer terugkom of nie. En ek moet sê met die volwassenes het ek agtergekom baie min van daardie sake kom werklik terug hof toe."

4. "I think they fulfil the same purpose. Because with adults: let us say there is case of domestic violence - you sometimes when reading the docket you realise 'no', there is not actually a problem, it is just that these people needs help."

5. "Ek sou sê dit hang van geval tot geval af, die ernstigheid van die klag en so aan. Ek sou tog sê die doel is maar dieselfde. Hulle leer lewensvaardighede aan. Jy leer hulle maar basies hoe om die regte ding te doen."

6. "Ja. Daar is sekere misdrywe wat - opgeskorte vonnisse help nie vir hulle nie. Hy het 'n opgeskorte vonnis maar - ek meen soos aanranding. Baie van hulle moet 'n kursus deurloop vir 'anger management'. Want anders gaan hy terug huis toe en wat gebeur? Oor twee weke verloor hy weer sy humeur."

7. "Ja, tog, want die mense deurloop programme wat hulle help om as beter mense die samelewing in te gaan."

Uittreksels uit die landdroste se verbale response:

1. "Nee, ek dink dit gaan tog maar oor rehabilitasie. Om nie deur die strafproses te gaan nie, maar eerder 'n ander paadjie te volg en dalk die persoon reg te help op 'n ander manier as 'n kriminele rekord. So vir my is dit maar basies dieselfde doel."

2. "Ek dink in 'n meerder mate kan dit dieselfde doel dien, want ek voel 'n volwassene het meer verantwoordelikheidsin as 'n kind. Met ander woorde, hy sal besef dat hy meer probleme het - ja."

3. "Nee. Volwassenes behoort verantwoordelikheid te neem vir hulle dade. Hulle weet wat hulle doen is verkeerd as hulle hulle skuldig maak aan misdade."

\begin{tabular}{|l|l|l|l|l|l|}
\hline Response (Totaal) & $2(20 \%)$ & $3(30 \%)$ & $1(10 \%)$ & $4(40 \%)$ & 0 \\
\hline
\end{tabular}


Die response op die vraelys (tabel 2) het aangedui dat vyf respondente (50\%) die doel met die afwending van jeugdiges en volwassenes basies as soortgelyk beskou het, terwyl vier (40\%) die teenoorgestelde mening gehuldig het. Daar is tydens die onderhoude getrag om hierdie anomalie op te klaar. Die verbale response wat in hierdie verband verkry is, word in tabel 3 vervat.

Uit 'n vergelyking van die inhoudelikes van tabelle 2 en 3 en die onderhoude het dit eerstens geblyk dat, alhoewel vier van die respondente aanvanklik die doel as verskillend beskou het, drie na nabetragting ietwat van mening verander het. Uiteindelik het $90 \%$ van die respondente dit as basies dieselfde beskou. Hulle het dit gesien as 'n geleentheid vir hetsy rehabilitasie, die vermyding van 'n kriminele rekord, 'n alternatief tot gevangenisstraf en of 'n geleentheid vir die neem van eie verantwoordelikheid.

Dit het egter tweedens geblyk dat daar wel 'n klemverskil in die hantering van die betrokke twee groepe behoort te bestaan, naamlik dat daar in die hantering van volwassenes baie meer klem op die uitlewing van hul verantwoordelikheidsin geplaas moet word.

\section{Kriteria vir die seleksie van volwasse oortreders}

Al tien die respondente het aangedui dat hulle nie bewus is van spesifieke kriteria vir die seleksie van volwasse oortreders vir afwending nie. Daar is in hierdie verband slegs bre $\ddot{e}$ riglyne in die handleiding van die Nasionale Vervolgingsgesag (NVG, 1999:12). Dit sluit onder andere in dat afwending nie geskik is vir ernstige misdade soos moord, roof met verswarende omstandighede of verkragting nie. Oortreders met vorige oortredings en diegene wat reeds tydens 'n vorige geleentheid deur afwending gegaan het, moet slegs in uitsonderlike gevalle weer oorweeg word. Daar moet ook in ag geneem word of die oortreder oor 'n vaste woonadres beskik, verantwoordelikheid vir die misdryf aanvaar en bereid is om by 'n program in te skakel.

Die gebrek aan spesifieke kriteria het meegebring dat daar in beide die vraelys en onderhoude uitgebreide aandag aan die betrokke onderwerp geskenk is. In hierdie verband is daar gelet op beide die tipe individu wat vir moontlike seleksie oorweeg kan word en die tipe misdade wat in- en uitgesluit behoort te word.

Daar is met behulp van die literatuurstudie tien oortrederseienskappe wat in die oorweging van afwending in ag geneem kan word, geïdentifiseer. Dit is in die vraelys vervat en die respondente moes op 'n vyfpunt Likert-tipe skaal aandui in watter mate hulle elke eienskap/kriterium as belangrik of onbelangrik beskou. Die resultate hiervan word in tabel 4 opgesom. 
TABEL 4

SELEKSIE-KRITERIA: TIPE INDIVIDU WAT OORWEEG KAN WORD

\begin{tabular}{|c|c|c|c|c|c|}
\hline EIENSKAPPE & \begin{tabular}{|} 
Kategorie 1: \\
Baie belangrike \\
kriterium/Very \\
important \\
criterion
\end{tabular} & $\begin{array}{c}\text { Kategorie 2: } \\
\text { Belangrike } \\
\text { kriterium/ } \\
\text { Important } \\
\text { criterion }\end{array}$ & $\begin{array}{c}\text { Kategorie 3: } \\
\text { Neutraal/ } \\
\text { Neutral }\end{array}$ & \begin{tabular}{|} 
Kategorie 4: \\
Onbelangrike \\
kriterium/ \\
Unimportant \\
criterion
\end{tabular} & $\begin{array}{c}\text { Kategorie 5: } \\
\text { Geensins } \\
\text { belangrik } \\
\text { nie/ Of no } \\
\text { importance } \\
\text { at all }\end{array}$ \\
\hline $\begin{array}{l}\text { 1. Die oortreder moet } \\
\text { moniteerbaar wees }\end{array}$ & $\begin{array}{c}8 \\
(80 \%)\end{array}$ & $\begin{array}{c}2 \\
(20 \%)\end{array}$ & - & - & - \\
\hline $\begin{array}{l}\text { 2. Moet beskik oor'n } \\
\text { vaste woonadres }\end{array}$ & $\begin{array}{c}6 \\
(60 \%)\end{array}$ & $\begin{array}{c}4 \\
(40 \%)\end{array}$ & - & - & - \\
\hline $\begin{array}{l}\text { 3. Moet'n inkomste } \\
\text { verdien }\end{array}$ & - & $\begin{array}{c}3 \\
(30 \%)\end{array}$ & $\begin{array}{c}2 \\
(20 \%)\end{array}$ & $\begin{array}{c}5 \\
(50 \%)\end{array}$ & - \\
\hline $\begin{array}{l}\text { 4. Moet verantwoor- } \\
\text { delikheid vir die } \\
\text { oortreding aanvaar }\end{array}$ & $\begin{array}{c}8 \\
(80 \%)\end{array}$ & $\begin{array}{c}2 \\
(20 \%)\end{array}$ & - & - & - \\
\hline $\begin{array}{l}\text { 5. Daar moet 'n af- } \\
\text { wendings-program } \\
\text { in plek wees vir } \\
\text { die spesifieke } \\
\text { oortreding } \\
\end{array}$ & $\begin{array}{c}9 \\
(90 \%)\end{array}$ & $\begin{array}{c}1 \\
(10 \%)\end{array}$ & - & - & - \\
\hline $\begin{array}{l}\text { 6. Die beskuldigde } \\
\text { moet bereid wees } \\
\text { om deel te neem } \\
\text { aan die af- } \\
\text { wendings-program }\end{array}$ & $\begin{array}{c}8 \\
(80 \%)\end{array}$ & $\begin{array}{c}2 \\
(20 \%)\end{array}$ & - & - & - \\
\hline $\begin{array}{l}\text { 7. Die oortreder moet } \\
\text { bereid wees om } \\
\text { hom/haar aan } \\
\text { ander voorwaardes } \\
\text { (bv. om skade te } \\
\text { herstel) te } \\
\text { onderwerp }\end{array}$ & $\begin{array}{c}8 \\
(80 \%)\end{array}$ & $\begin{array}{c}1 \\
(10 \%)\end{array}$ & $\begin{array}{c}1 \\
(10 \%)\end{array}$ & - & - \\
\hline $\begin{array}{l}\text { 8. Die erns van die } \\
\text { misdryf }\end{array}$ & $\begin{array}{c}8 \\
(80 \%)\end{array}$ & $\begin{array}{c}2 \\
(20 \%)\end{array}$ & - & - & - \\
\hline $\begin{array}{l}\text { 9. Het die oortreder } \\
\text { afhanklikes? }\end{array}$ & - & $\begin{array}{c}5 \\
(50 \%)\end{array}$ & $\begin{array}{c}4 \\
(40 \%)\end{array}$ & $\begin{array}{c}1 \\
(10 \%)\end{array}$ & - \\
\hline $\begin{array}{l}\text { 10. Die moontlikheid } \\
\text { dat die misdryf } \\
\text { herhaal sal word }\end{array}$ & $\begin{array}{c}5 \\
(50 \%)\end{array}$ & $\begin{array}{c}5 \\
(50 \%)\end{array}$ & - & - & - \\
\hline
\end{tabular}


Tabel 4 toon aan dat die volgende ses eienskappe 'n "telling" van $80 \%+$ in kategorie 1 (Baie belangrik) behaal het en dus pertinente aandag in die seleksieproses behoort te geniet.

- Daar moet 'n afwendingsprogram in plek wees vir die spesifieke oortreding (90\%).

- Die oortreder moet moniteerbaar wees $(80 \%)$.

- Hy/sy moet verantwoordelikheid vir die oortreding aanvaar (80\%).

- Die beskuldigde moet bereid wees om deel te neem aan die afwendingsprogram (80\%).

- Die oortreder moet bereid wees om hom/haar te onderwerp aan ander voorwaardes, byvoorbeeld die vervanging van skade berokken $(80 \%)$.

- Die erns van die misdryf (80\%).

Respondente kon ook ander eienskappe tot die lys byvoeg. Dit het twee verdere kriteria opgelewer, naamlik dat die oortreder berou moet toon en oor 'n goeie prognose vir rehabilitasie moet beskik.

Omdat bestaande riglyne slegs vermeld dat afwending nie vir ernstige misdade oorweeg kan word nie, was dit nodig om in die ondersoek te let op die spesifieke misdrywe wat in die keuring van potensiële kandidate in- en uitgesluit moet word. Die vraelys het gevolglik 'n lys bevat van 16 misdrywe wat die respondente in hierdie verband moes beoordeel. Die data wat hierdeur gegenereer is, word in tabel 5 opgesom. In die tabel is 'n afsnypunt van $60 \%$ as 'n basis vir insluiting en uitsluiting gebruik.

TABEL 5

'N OPSOMMING VAN MISDRYWE WAT TYDENS SELEKSIE IN- EN UITGESLUIT BEHOORT TE WORD

\begin{tabular}{|c|c|}
\hline Misdrywe wat veral ingesluit moet word* & Misdrywe wat veral uitgesluit moet word* \\
\hline 1. Aanranding & 1. Ontvoering \\
\hline 2. Gesinsgeweld & 2. Vuurwapens en ammunisie \\
\hline 3. Dwelmverwant (bv. besit van dagga) & 3. Huisbraak \\
\hline 4. Alkoholverwant (bv. bestuur onder invloed) & 4. Moord \\
\hline 5. Diefstal (van 'n kleiner omvang) & 5. Verkragting \\
\hline \multirow{4}{*}{$\begin{array}{l}\text { 6. Crimen injuria (in } 70 \% \text { van die onderhoude } \\
\text { is dit as 'n kriterium genoem) }\end{array}$} & 6. Roof \\
\hline & 7. Veediefstal \\
\hline & 8. Onsedelike aanranding \\
\hline & 9. Bedrog \\
\hline
\end{tabular}

* Een misdryf, te wete agterstallige onderhoud, het 'n 50\%-insluiting- vs. 50\%-uitsluitingresponskoers opgelewer.

Die respondente het ook die geleentheid gekry om ander misdrywe tot die lys toe te voeg wat by die positiewe oorweging van kandidate ingesluit moes word, naamlik kinderverwaarlosing, kwaadwillige saakbeskadiging van eiendom, korrupsie en Artikel 14(b) van die Wet op Seksuele Misdrywe (Wet 23/1957). Laasgenoemde artikel handel oor ontug met 'n meisie onder die ouderdom van 16 jaar en 'n seun onder die ouderdom van 19 jaar. 
Die respondente se denke rondom die misdade wat in- en uitgesluit moes word, is ook tydens die onderhoude in diepte verken. Dit het in 'n groot mate die resultate wat met die vraelys behaal is, bevestig. Bykomend het hulle aangedui dat veral sake waarin gesinsgeweld, crimen injuria en aanrandings 'n pertinente rol speel, geskik vir afwending is. Die respondente het veral negatief teenoor oortreders met vorige veroordelings gestaan. So het een aangedui dat hy/sy nie 'n persoon met meer as twee oortredings sal oorweeg nie en sewe ander het tweede oortreders uitgesluit. Al die respondente was dit egter eens dat, alhoewel hulle riglyne vir die identifisering van moontlike volwasse kandidate vir afwending sou verwelkom, alle sake uiteindelik op hul eie meriete oorweeg behoort te word.

\section{Mate waarin huidige verslae aan verwagtinge voldoen}

$\mathrm{Na}$ die identifisering van potensiële kandidate word daar dikwels verslae vanaf proefbeamptes oor die wenslikheid van vervolging aangevra. Omdat hierdie verslae 'n sleutelrol in die totale proses speel, is daar in die ondersoek op twee fasette daarvan gefokus. Dit is naamlik die mate waarin huidige verslae aan die betrokke verteenwoordigers van die Departement van Justisie se verwagtinge voldoen en die inhoud en struktuur van die verslae.

Die vraelys het twee vrae bevat waarin respondente moes aandui in watter mate bestaande wenslikheid van vervolging-verslae ten opsigte van onderskeidelik jeugdiges en volwassenes aan hul verwagtinge voldoen. In hierdie verband het agt respondente vermeld dat dit rakende jeugdiges die meeste van die tyd was, terwyl twee aangedui het dat dit net "soms" die geval is. Rakende volwassenes was die verspreiding ses vir "meeste van die tyd" en een vir "soms". Drie (30\%) van die respondente het nog nooit hierdie tipe verslae aangevra nie.

Die totale aangeleentheid is tydens die onderhoude verder verken. Die landdroste en beheeraanklaers se kernresponse word in tabel 6 weergegee.

Die oorgrote meerderheid van die respondente was redelik tevrede met die verslae en het meestal, ten spyte van sommige gebreke, groot waarde daaruit geput. Ander het dit as onbevredigend of swak beoordeel. Uit die onderhoude het dit geblyk dat hierdie wisselende respons toegeskryf kan word aan sommige proefbeamptes wat hulle goed van hul taak kwyt, terwyl ander nie so suksesvol was nie. Laasgenoemde het gemanifesteer in oppervlakkige ondersoeke en onvolledige verslae of verslae met inligting wat nie vir die aanklaers/landdroste van waarde was nie. 


\section{TABEL 6}

\section{DIE MATE WAARIN HUIDIGE VERSLAE AAN VERWAGTINGE VOLDOEN}

\section{KERNVRAAG:}

Sou u oor die algemeen meen dat die inhoud van die verslae aan u verwagtinge

voldoen?/ In general, do the contents of the Desirability of Prosecution Report meet your expectation?

Uittreksels uit die beheeraanklaers se verbale response:

1. "Yes, they do" / "Ja" (Twee beheeraanklaers).

2. “... op 'n stadium het ons nogal gesukkel met die kwaliteit van die verslae. Die inligting daarin was onvoldoende. Dit het nou - in 'n sekere mate... verbeter en die verslae is gewoonlik redelik... Dit is $99 \%$ bruikbaar en verskaf voldoende inligting."

3. "Nee glad nie. Daardie verslae is baie gebrekkig. Dit is baie oorsigtelik en dit is heeltemal te eensydig geskryf. Ons kry nie regtig 'n totale persepsie oor die persone se geskiedenis nie. Familiebronne word nie geraadpleeg nie."

4. "Ek sou sê ja, meeste van die gevalle. Ja."

5. "Dit hang af van die ondervinding van die personeel."

6. "Die verslae wat an ons voorsien word, is baie volledig. Maar dit is belangrik dat die maatskaplike werker moet weet wat verwag word. Ons maatskaplike werkers skryf tot verslae vir die Hooggeregshof, maar hulle is oorwerk, want daar is nie genoeg om die werk te doen nie."

Uittreksels uit die landdroste se verbale response:

7. “...ek is tevrede met die terugvoer wat ek kry en die 'effort' wat hulle daarin sit en die aanbevelings wat hulle maak."

8. "Weet jy ek het laas daarmee gewerk toe ek aanklaer was, maar ek het redelik daarmee gewerk toe ek by die streekhof was. Op daardie stadium was dit nog 'n nuwe begrip, maar die inhoud van die verslae was dikwels baie oppervlakkig. Dit is meer 'n vraelys wat opgestel word, 'n pro-forma wat kortliks ingevul word en dit gee nie regtig vir jou die agtergrond van die persoon waarmee jy te doen het nie."

9. "Nee, die verslae is baie swak."

Tydens die onderhoude is respondente ook versoek om hul siening rakende die moontlike redes vir onbevredigende verslaggewing weer te gee en aanbevelings vir die verbetering daarvan te maak. Dit het die volgende ses tipes response opgelewer:

- Proefbeamptes moet spesifiek opleiding rakende die skryf van die verslae ontvang.

- Indien formele afwendingsprogramme vir volwassenes in plek is, kan aanbevelings wat benutbaar is, gemaak word.

- 'n Gebrek aan tyd en 'n tekort aan proefbeamptes het 'n negatiewe invloed op die daarstelling van kwaliteitverslae.

- 'n Tekort aan hulpbronne - soos vervoer, telefone en rekenaars - het tot gevolg dat die verslae nie altyd voorsien kan word nie, of dat die kwaliteit van die verslae swak is.

- Die verslae moet oor 'n sterk psigo-sosiale komponent beskik.

- Verbeterde kommunikasie tussen rolspelers en koördinering van dienste kan baie probleme uitskakel. 


\section{Die voorgestelde struktuur en inhoud van verslae}

Daar kon geen Suid-Afrikaanse bron gevind word wat die vereistes, waaraan 'n wenslikheid van vervolgings-verslag vir volwassenes moet voldoen, uitspel nie. Die enigste bron wat wel enkele indikatore hieroor bevat het, was Collopy et al. (2001:79-81) se publikasie Handy Hints for Prosecutors. Hierdie bron, tesame met buitelandse publikasies (Jenkins, 1995:129-136; Johnson, 2004:1-6; Mosley, 2004:1; Nolo, 2005:5), is as basis gebruik om 'n lys van die onderwerpe wat in die betrokke tipe verslae gedek kon word, op te stel. Die onderwerpe is in die vraelys vervat en respondente moes met behulp van 'n vyfpunt Likert-skaal aandui in watter mate hulle verwag dat 'n gegewe onderwerp gedek moet word.

In die interpretasie van die data wat deur die vraelyste opgelewer is, is $70 \%$ as basiese afsnypunt gebruik. Derhalwe is die onderwerpe wat 'n $70 \%$ en hoër "punt" in die Strongly agree-afdeling behaal het, as noodsaaklik gesien. Dié wat oorwegend in die Agree-kategorie geval het, is as belangrik beskou terwyl dié wat 'n neutrale of negatiewe respons opgelewer het, as "bykomende inligting" getipeer is. Die resultate van hierdie proses word in tabel 7 opgesom.

TABEL 7

'N GRADERING VAN DIE INLIGTING WAT IN DIE VERSLAG INGESLUIT KAN WORD

\begin{tabular}{|c|c|c|}
\hline Noodsaaklike Inligting & Belangrike Inligting & Bykomende Inligting \\
\hline 1. Persoonlike inligting & 1. Behuising en omgewing & 1. Religieuse faktore \\
\hline 2. Agtergrond van die oortreder & $\begin{array}{l}\text { 2. Huwelikslewe en } \\
\text { interpersoonlike verhoudings }\end{array}$ & \multirow[t]{8}{*}{$\begin{array}{l}\text { 2. Stokperdjies en ande } \\
\text { aktiwiteite }\end{array}$} \\
\hline 3. Vorige veroordelings & $\begin{array}{l}\text { 3. Opleiding/skolastiese } \\
\text { onderrig }\end{array}$ & \\
\hline 4. Houding teenoor die misdryf & $\begin{array}{l}\text { 4. Sielkundige en fisiese } \\
\text { aspekte }\end{array}$ & \\
\hline $\begin{array}{l}\text { 5. Mate waarin die oortreder } \\
\text { verantwoordelikheid vir die } \\
\text { pleging van die misdryf neem }\end{array}$ & $\begin{array}{l}\text { 5. Werksgeskiedenis en } \\
\text { finansies }\end{array}$ & \\
\hline $\begin{array}{l}\text { 6. Die impak op die slagoffer of } \\
\text { skade aan eiendom }\end{array}$ & $\begin{array}{l}\text { 6. Redes vir pleging van die } \\
\text { misdryf }\end{array}$ & \\
\hline $\begin{array}{l}\text { 7. Die moontlikheid dat die } \\
\text { misdryf herhaal kan word }\end{array}$ & $\begin{array}{l}\text { 7. Ander faktore wat die } \\
\text { misdryf kan regverdig }\end{array}$ & \\
\hline 8. Evaluasie & \multirow{2}{*}{$\begin{array}{l}\text { 8. Of die oortreder 'n deelnemer } \\
\text { of inisieerder was }\end{array}$} & \\
\hline 9. Aanbeveling & & \\
\hline
\end{tabular}


Die respondente kon ook bykomende onderwerpe tot die lys toevoeg. In hierdie verband het hulle verwag dat die verslae ook inligting moes bevat oor:

- die agtergrond van die slagoffer en die impak wat die misdryf op slagoffers uitoefen het;

- die alternatiewe opsies wat uitgeoefen kan word indien afwending nie slaag nie;

- die moontlike alternatiewe opsies in gevalle waar 'n saak te "dun" (swak) is vir vervolging; en

- die beskikbaarheid van 'n toepaslike afwendingsprogram vir die oortreder.

Gesamentlik het die response daarop gedui dat die landdroste en beheeraanklaers veral in die oortreder as mens en in sy/haar wisselwerking met die misdaad belang stel. Hulle wou ook weet watter impak die misdaad op die slagoffer gehad het. Bykomend is daar van die proefbeampte verwag om 'n weldeurdagte aanbeveling, wat al die fasette van afwending in ag neem, te maak.

Tydens die onderhoude het van die respondente die gebrek aan geskikte afwendingsprogramme in sommige sentra as 'n ernstige leemte in die huidige stelsel beskou. Die gedagte is geopper dat die programme wat reeds binne korrektiewe dienste benut word (bv. herstellende reg en mediasie), in sodanige gevalle as 'n basis gebruik moet word.

\section{BELANGRIKSTE BEVINDINGE}

Daar sal vervolgens aan die hand van beide die literatuurstudie en empiriese ondersoek op die belangrikste bevindinge van die ondersoek gelet word.

Beskikbare literatuur en wetgewing het aangetoon dat die aard, doel en voordele van die afwending van jeugdiges en van volwassenes wesenlik dieselfde is. Dit is basies die kanalisering van prima facie-sake weg van die strafregtelike sisteem af ten einde 'n beskuldigde (hetsy 'n jeugdige of volwassene) die geleentheid te gee om in die gemeenskap te rehabiliteer.

Die vraag het egter ontstaan waarom die afwending van volwassenes dan nie in 'n groter mate in die praktyk benut word nie. Uit die empiriese ondersoek het dit geblyk dat die oorgrootte meerderheid landdroste en beheeraanklaers wel baie positief teenoor die betrokke opsie staan. Daar is egter veral die volgende vier algemene struikelblokke wat die volle benutting daarvan strem:

- In teenstelling met jeugdiges, bestaan daar geen duidelik beleid en prosedure vir die afwending van volwassenes nie. Dit bring mee dat nie al die rolspelers van die betrokke opsie bewus is of dit as 'n prioriteit beskou nie. So byvoorbeeld dra staatsaanklaers nie altyd kennis van die feit dat wenslikheid van vervolging-verslae ook ten opsigte van volwassenes aangevra kan word nie, en fokus proefbeamptes op die afwending van jeugdiges.

- Die wenslikheid van vervolging-verslae voldoen nie altyd aan die hoffunksionarisse se verwagtinge nie.

- Dit kan enersyds aan die werksoorbelading van proefbeamptes en die gepaardgaande oppervlakkige ondersoeke en verslae toegeskryf word.

- Andersyds dra sommige (veral nuwe) proefbeamptes nie genoegsame kennis van al die vereistes waaraan die verslae moet voldoen nie. Dit gee aanleiding tot verslae wat soms onbruikbaar vir die hof is. 
- 'n Gebrek aan genoegsame hulpbronne dra ook by tot onbevredigende ondersoeke en verslae deur proefbeamptes.

- Laastens bestaan daar nie in alle sentra programme wat in die afwending van volwassenes gebruik kan word nie.

Daar kan tot die oorhoofse gevolgtrekking gekom word dat daar 'n groot behoefte aan die afwending vir volwassenes bestaan, maar dat daar slegs in hierdie behoefte voorsien sal kan word as beide die departemente van Maatskaplike Ontwikkeling en Justisie bepaalde struktureel-funksionele veranderinge ondergaan. Dit sluit in die voorsiening van meer proefbeamptes aan howe, die uitklaring van die verwagtinge rakende die afwending van volwassenes op beleidsvlak en die belyning van die prosedure en verwagtinge rakende die inhoud en voorsiening van verslae.

Twee van die vrae wat na aanleiding van die voorafgaande beantwoord moet word, is hoe daar gesorg kan word dat toepaslike volwasse oortreders geselekteer en benutbare verslae oor hulle aan die hof voorsien kan word. Die riglyne wat in hierdie verband uit die ondersoek na vore gekom het, geniet vervolgens aandag.

\section{RIGLYNE VIR DIE BENUTTING VAN AFWENDING VIR VOLWASSENES EN VERBETERDE VERSLAGGEWING}

Daar sal vervolgens op drie stelle riglyne gefokus word. Dit is naamlik die tipe oortreders wat veral geskik vir afwending is, die tipe misdrywe wat veral oorweging behoort te geniet en die onderwerpe wat veral in verslaggewing gedek moet word.

Daar moet in die seleksieproses gefokus word op volwasse oortreders wat:

- oor 'n goeie prognose vir rehabilitasie beskik;

- verantwoordelikheid vir die oortreding aanvaar en berou toon;

- bereid is om aan die afwendingsprogram deel te neem en hom-/haarself ook aan ander voorwaardes te onderwerp;

- nie 'n te ernstige oortreding gepleeg en nie verskeie vorige veroordelings het nie; en

- moniteerbaar is.

Alhoewel die ernstigheidsgraad van die oortreding en die omstandighede waarin dit gepleeg is, altyd in gedagte gehou moet word, is daar wel sekere tipes misdrywe wat meer toepaslik vir afwending is as ander. Die ses misdrywe wat veral in eersgenoemde kategorie val, is:

- crimen injuria;

- dwelmverwante oortredings (bv. besit van dagga);

- alkoholverwante oortredings (bv. bestuur onder die invloed);

- gesinsgeweld;

- diefstal (van 'n minder ernstige aard);en

- aanranding.

Ten einde die hof se behoeftes te bevredig, moet 'n proefbeampte se wenslikheid van vervolging-verslag veral die volgende onderwerpe deeglik dek.

- Die oortreder se persoonlike besonderhede.

- Die oortreder se agtergrond. 
- Sy/haar vorige veroordelings.

- Sy/haar houding teenoor die misdryf.

- Mate waarin hy/sy verantwoordelikheid vir die pleging van die misdryf neem.

- Die skade wat aan die slagoffer of eiendom gedoen is.

- Die moontlikheid dat die misdryf herhaal kan word.

- 'n Evaluasie/assessering (van onder andere die oortreder as individu, die mate waarin hy/sy aan die oogmerke van afwending voldoen en die mate waarin hy/sy rehabilitatiewe waarde uit die proses sal kan put).

- 'n Aanbeveling(s) (wat insluit die toewysing aan 'n geskikte afwendingsprogram en die alternatiewe opsies wat uitgeoefen kan word indien afwending nie slaag nie).

Rakende die riglyne moet dit in gedagte gehou word dat elke geval as uniek beskou moet word en dat die oogmerke van straf, wat vergelding, voorkoming en hervorming insluit, altyd hierby behoort aan te sluit.

\section{OORKOEPELENDE AANBEVELINGS}

Alhoewel die ondersoek waarop hierdie uiteensetting gegrond is, slegs van 'n verkennende aard was, is genoegsame bewyse gevind om tot die gevolgtrekking te kom dat die afwending van volwassenes 'n waardevolle, maar onderbenutte opsie verteenwoordig. Om die volle potensiaal daarvan te kan benut, behoort die volgende vyf aanbevelings ten uitvoer gebring te word:

- Beide die departemente van Justisie en van Maatskaplike Ontwikkeling behoort volle kennis van die moontlikheid van die afwending van volwassenes te neem en dit via hul bestuurstrukture aan onder andere die tersaaklike hoffunksionarisse en proefbeamptes deur te gee. Dit sal 'n belangrike element in die "bemarking" van die betrokke opsie uitmaak.

- Daar behoort daadwerklike aandag aan die ontwerp en implementering van afwendingsprogramme vir volwassenes in al die belangrike sentra geskenk te word. Die ondersoek het aangetoon dat die programme 'n sleutelfaktor in die uiteindelike sukses of mislukking van die opsie sal wees.

- Daar moet spesifieke riglyne geformuleer word vir die tipe beskuldigdes en tipe oortredings wat in die keuring van kandidate moet geld. Die bevindinge van hierdie ondersoek en die riglyne wat daaruit voortgevloei het, kan hierin as basis dien.

- Proefbeamptes behoort gespesialiseerde opleiding te ontvang in die hantering van ondersoeke na die omstandighede van die volwasse oortreders wat vir afwending oorweeg word, asook in die skryf van die gepaardgaande wenslikheid van vervolging-verslae. Rakende die aspekte wat in hierdie ondersoek gedek en in die verslae vervat moet word, kan die bevindinge van hierdie ondersoek as riglyne dien.

- Daar behoort navorsing oor die betrokke aangeleentheid wat die hele Suid-Afrika sal dek gedoen te word. So 'n ondersoek sal ook proefbeamptes moet betrek en onder andere moet let op die struikelblokke wat effektiewe dienslewering aan die volwasse oortreder belemmer. Dit kan ook die vereistes waaraan afwendingsprogramme vir volwassenes moet voldoen, insluit. 
Die implementering van die aanbevelings kan 'n bepalende invloed hê op die lewering van dienste deur proefbeamptes aan volwasse oortreders en die gepaardgaande afwending. Dit behoort by te dra tot die verdere ontwikkeling van die omvang en standaard van hierdie gespesialiseerde diens tot voordeel van die oortreders, regslui, proefbeamptes en die gemeenskap in die breë. Sodoende sal dit as teenwig vir die reeds oorvol korrektiewe sentra kan dien en terselfdertyd 'n beter toegeruste persoon die gemeenskap instuur.

\section{BIBLIOGRAFIE}

BADENHORST, C. \& CONRADIE, H. 2004. Diversion: the present position and proposed future provisions. Acta Criminologica, 17(2):115-130.

COLlOPY, A., DAFFUE, B., KRIGE, R., MATZKE, E., PICKETT, G., SIBEKO, P., PHOSHOKO, Y. \& MULEA, P. 2001. Handy hints for prosecutors. Pretoria: National Director of Public Prosecutors.

JENKINS, L.A. 1995. Pre-trial diversion strategies for drug involved offenders: focus on social work involvement. Journal of Offender Rehabilitation, 22(3/4):129-140.

JOHNSON, D. 2004. Tempe Social Services: diversion services. Beskikbaar: http://wwwtempe.gov/ socialservices/socialdiversion.htm. [Datum van gebruik: 05/04/2005].

MOSLEY, J. 2004. Government in Shelby County: pre-trial services. Beskikbaar: http://www. shelbycountytn.gov/FirstPortal/dotShowdoc/Government/CountyServices [Datum van gebruik: 05/04/2005].

NASIONALE VERVOLGINGSGESAG VAN SUID-AFRIKA sien NVG.

NIEMAN, A. 1998. A therapeutic programme for parents of youth offenders. Johannesburg: Universiteit van Suid-Afrika. (MA tesis)

NOLO. 2005. Sentencing alternatives: from incarceration to diversion. Beskikbaar: http://www.nolo.com/article.cfm/ObjectID/ [Datum van gebruik: 05/04/2005].

NVG (Nasionale Vervolgingsgesag van Suid-Afrika). 1999. Beleidsriglyne. Pretoria: Nasionale Vervolgingsgesag van Suid-Afrika.

STEYN, F. 2001. Impediments in the management of young offenders in the Free State. Article 40. Beskikbaar: http://www.communitylawcentre.org.za/children/2001art40/vol3no1young. php [Datum van gebruik: 05/04/2005].

STRYDOM, H. \& VENTER, L. 2002. Sampling and sampling methods. In: DE VOS, A.S. (ed) Research at grass roots. Pretoria: Van Schaik Uitgewers: 197-209.

SUID-AFRIKA. 1957. Wet op Seksuele Midrywe. no. 23 van 1957. Pretoria: Staatsdrukker.

SUID-AFRIKA. 1977. Strafproseswet, no. 51 van 1977. Pretoria: Staatsdrukker.

SUID-AFRIKA. 1991. Wet op Proefdienste, no. 116 van 1991. Pretoria: Staatsdrukker.

SUID-AFRIKA. 2002. Wysigingswet op Proefdienste, no. 35 van 2002. Pretoria: Staatsdrukker.

Wet 116/1991 sien SUID-AFRIKA. 1991. Wet op Proefdienste.

Wet 35/2002 sien SUID-AFRIKA. 2002. Wysigingswet op Proefdienste.

Wet 51/1977 sien SUID-AFRIKA. 1977. Strafproseswet. 
306

WETTE sien SUID-AFRIKA.

WOOD, C. 2003. Diversion in South Africa: a review of policy and practice, 1990-2003. Beskikbaar: http://www.iss.co.za/pubs/papers/79/Paper79.html [Datum van gebruik: 17/03/2005].

Me Elizabeth Vergottini, maatskaplike werker, Departement van Maatskaplike Ontwikkeling; prof Mike Weyers, Skool vir Psigo-Sosiale Gedragswetenskappe: Vakgroep Maatskaplike Werk, Noordwes-Universiteit: Potchefstroomkampus, SuidAfrika. 